AFRICAN

\title{
Situating Somali Piracy in Japanese Security Policy
}

\author{
by Robert Attwell \\ Chevening Scholar \\ University of Edinburgh
}

\begin{abstract}
This paper examines Tokyo's engagement with Somali piracy and discusses what it reveals about Japan's overall security posture. I argue that Japan's response to Somali piracy highlights the continued salience of domestic political processes and embedded anti-militarist norms in moulding Tokyo's responses to emergent threats, of which piracy is a prime example. This is evidenced by the fact that the Japan Coast Guard (JCG), rather than the Japanese Maritime Self-Defence Force (JMSDF), is primarily responsible for Japan's anti-piracy mission in the Gulf of Aden. Additionally, I draw attention to the economic logic underpinning Japan's approach to security and posit that the defence of sea lanes links maritime security issues to continued economic security to explain why combatting maritime piracy is important to Tokyo.
\end{abstract}

\section{Debating Japanese security, international pressures versus domestic norms}

Japan's post-war constitution was introduced by the United States (US)-led Occupation government in 1946, roughly a year after Japan's defeat in the Second World War by the US and its allies and the atomic bombings of Hiroshima and Nagasaki. A key element of the new constitution was Article 9, the "peace clause," which renounced war as a tool of foreign policy and dispute settlement and forbade Japan from maintaining a military (Article 9, Japan Constitution; Hughes, 2004: 21). Japan became firmly embedded in the US-led capitalist camp during the Cold War and bilateral norms informed by its alliance with Washington dominated Tokyo's external 
AFFAIRS

relations during this period. In terms of security policy, the Yoshida Doctrine became the dominant approach. The Yoshida Doctrine was the brainchild of then Prime Minister Yoshida Shigeru and it emphasised security dependence on the US, institutionalised via the Japan-US security alliance in 1960, and a prioritisation of post-war economic recovery and growth (Hook et al., 2012: 84-85; Yamaguchi, 2012: 81). In return for the US protection, Japan had to host a network of US military bases, notably in Okinawa which would remain under US administration until 1972, in order to help Washington project its power into Asia (Hughes, 2004: 22). Japan did have to take on some responsibility for its security, especially its internal security. Labour activism was perceived to be a particularly important threat owing to concerns about the advance of communism in East Asia. These fears came to the fore during the Korean War (Yamaguchi, 2012: 83). The National Police Reserve (NPR) was formed in 1950. This was quickly followed by the formation of the National Safety Force (NSF) in 1952 and the Japanese Self-Defence Force (SDF) and Japan Defence Agency (JDA) in 1954. The SDF and JDA remain Japan's primary externally-focussed security institutions (Hughes, 2004: 22).

In terms of domestic society, the experience of war, as represented by the atomic bombings, combined with the post-war constitution led to the entrenchment of antimilitarist norms at the societal level. Opposition parties played, and continue to play, an important role in safeguarding anti-militarist norms (Hook et al., 2012: 85; Delamotte, 2012: 160-162). Additionally, polling data consistently shows that most Japanese citizens oppose constitutional revisions aimed at scrapping or altering Article 9. Recent changes in the interpretation of the constitution and the new legislation which allows for collective self-defence by the current Abe administration resulted in protests, including at least one example in which a man self-immolated (Japan Times, 2014; BBC, 2014). Indeed, as Midford (2011) argues, Japanese public opinion against drastic security policy reforms and constitutional revisionism has remained remarkably consistent for decades.

Despite the continued salience of domestic and international constraints on its security policy, Japan has cautiously and incrementally expanded its international security profile since the end of the Cold War, albeit within normative and constitutional con- 


\section{AFRICAN \\ EAST-ASIAN \\ AFFAIRS \\ THE CHINA MONITOR}

straints. For example, the SDF is engaged in various peace-keeping operations and humanitarian assistance missions (Midford, 2011: 108; Aoi, 2012: 132-133; Delamotte, 2012: 160-162). The evolution of Japanese post-Cold War security posture has attracted considerable academic and policy-making interest. One of the key points of contention is the degree to which domestic variables, like pacifist norms, and international variables, like the rise of China, determine Japanese security policies (Hughes, 2014: 373). Neorealism posits that anarchy is the ordering principle of the international system and that states are beholden to no higher authority. Consequently, states must pursue power in order to secure themselves and their material interests. Inevitably this leads to conflict with other states, which are doing the same thing (Mearsheimer, 2001; Waltz, 1979). As noted by Hughes (2014: 373), neorealist interpretations of Japanese security policy can be divided into two camps: offensive realists and defensive realists. Both camps assume that the major influences on Japanese security policy arise from Japan's external environment. The former position argues that structural changes in the international system, specifically the relative decline of the US and the need to balance a rising China, Japan's regional rival, will force Tokyo to adopt an assertive military posture to match its economic standing. Japan will, offensive realists argue, inevitably "normalise" its security policy and military outlook to balance China (Mearsheimer, 2001; Waltz, 1993; Hughes, 2004).

Contrastingly, defensive realists argue that structural changes will induce milder security policy reforms in Japan. The relative decline of the US is not so great that Washington will abandon East Asia altogether. As such, the US-Japan alliance will balance a rising China and Japan will make modest reforms to its current defensive posture, striking a balance between dependence on the US and emergent threats from China. Richard Samuels refers to this balance as the Goldilocks Approach, not too close but not too far from the US and getting security "just right" (Samuels, 2007, 2006). Additionally, defensive realists predict that Japan will enhance its defensive capabilities whilst assuring its neighbours that it is not on a path to remilitarisation. Finally, Japan, defensive realists predict, will utilise its economic strength to pursue power via mercantilist policies (Heginbotham and Samuels, 1998; Green 2001). Overall, neorealist interpretations highlight the explanatory power of post-Cold War 
AFFAIRS

structural changes in studying Japan's evolving role in an increasingly complex and multipolar international system.

Constructivist scholars emphasise developments at the domestic level. They highlight domestic societal norms and identities, specifically anti-militarism and pacifism, as the defining features of Japanese foreign and security policy. Norms filter upwards from the societal level into the policy-making process. The consequence is a profound resistance to Japan taking on a more aggressive military posture (Katzenstein and Okawara, 1993). Indeed, Friman et al. (2006: 85) have questioned whether or not pacifist norms are an "immovable object." Ultimately they argue that as new threats emerge, the social norms evolve to accommodate them and that as the world becomes increasingly globalised the lines between internal and external threats become increasingly blurred (Friman et al., 2006: 85-86). Additionally, Katzenstein and Okawara (2008: 60) point out that security policy-making processes are diffused through multiple government ministries all with competing interests and identities. For example, the Ministry of International Trade and Industry (MITI) has an interest in securing Japanese economic interests and thereby ensure Japanese security and foreign policies are in line with mercantilism. The Ministry of Finance, for example, has an interest in balancing the national budget and this further restrains military advancement (Katzenstein and Okawara, 2008: 60). The overarching theme of constructivist analyses of Japanese security policy is that domestic forces play a key role in articulating Japanese security postures and that societal norms are particularly important.

\section{Linking economic and maritime security: piracy and shipping lanes}

In the decades following the Second World War, Japanese foreign policy doctrines and national security priorities have been underpinned by a certain economic logic. Indeed, Japan's prioritisation of the economic aspects of international relations has led several scholars to classify its foreign policy as mercantile realism (Heginbotham and Samuels, 1998). This economic logic is evident in the Yoshida Doctrine, Japan's first major post-war foreign policy doctrine. As mentioned earlier, the Yoshida Doctrine emphasised dependency on the US in security matters and a prioritisation of 


\section{AFRICAN \\ EAST-ASIAN \\ AFFAIRS

post-war economic recovery (Hook et al., 2012: 29; Yamaguchi, 2012: 81). Tokyo derived many significant economic benefits by becoming enmeshed in the US sphere of influence and capitalist camp during the Cold War. First, with US security guarantees being institutionalised in the 1960 ratification of the US-Japan alliance, Tokyo's defence expenditure remained low and has hovered around one per cent of the national budget for the past few decades (Akaha, 1991: 326). Even more significantly, Tokyo's partnership with Washington ensured that Japanese manufacturers had access to the US market (Hughes, 2004: 22). Washington also backed Japanese ascension to emerging international economic institutions. For example, Japan joined both the International Monetary Fund (IMF) and the General Agreement on Trade and Tariffs (GATT), the precursor to the modern World Trade Organisation (WTO), in 1952 and 1955 respectively (Hook et al., 2012: 343-344). It is evident that, in the early years of the Cold War, economic recovery was a priority and this fact is reflected in the Yoshida Doctrine.

Economic considerations continued to play a key role in shaping Japanese foreign and security doctrines in the latter half of the Cold War and into the post-Cold War period. This is observable in the concept of comprehensive national security. The concept of comprehensive national security gained popularity in Japan in the late 1970s and early 1980s and remains an important pillar of Japanese security policy today. The term was popularised by a 1978 joint report by the National Institute for the Advancement of Research (NIRA) and the Nomura Research Institute (Akaha, 1991: 324; Bradford, 2004: 484-485). Conceptually, comprehensive security builds on framework developed under the Yoshida Doctrine with its minimal focus on military affairs and prioritisation of economic development. However, US commitments to Asia following the defeat in Vietnam and the 1973-74 OPEC oil crisis forced Japan to reassess its security posture (Chapman et al., 1983; Akaha, 1991: 325-326). The 1973 oil crisis struck a nerve because it highlighted Japan's dependency on imported Middle Eastern oil and general lack of domestic resources (Yoshimatsu, 2014: 578). The Japanese economy was based on value-added production which depended on imported raw materials and the exportation of finished goods. This made the potential for disruptions to Japan's supply lines especially concerning for 
AFFAIRS

policy-makers (Graham, 2006: 10; Chapman et al., 1983: 232). Comprehensive national security developed as a recognition of Japan's economic vulnerability and the changing security environment in the latter half of the Cold War. Japanese policymakers, therefore, adopted a multifaceted approach to national security comprised of military and non-military dimensions. On the military front, Prime Minister Nakasone abandoned the policy limiting defence expenditure to less than one percent of Gross National Product (GNP) in 1985 and Tokyo became more receptive to US demands for more equitable defence burden-sharing. In non-military front, Japan made large financial contributions to various United Nations (UN) missions and substantially increased its humanitarian aid and official development assistance (ODA) programs (Akaha, 1991: 237-239). Domestically, Japan's technological and economic capabilities became vital to the maintenance of national security and policymakers came to regard economic decline as a major threat (Yoshimatsu, 2014: 578; Samuels, 2007: 143-144). Japan's concept of comprehensive national security, like the Yoshida Doctrine, highlights the importance of economic considerations in Japanese approaches to security.

Geography plays an important role in linking maritime security developments to Japanese concerns about economic security. East Asia is a maritime region and threats emanating from the sea play particularly important role in the regional security agenda. Indeed, according to Paik (2005: 15), most of the major security threats in East and Southeast Asia emanate from maritime concerns. These could include traditional security threats such as territorial disputes or naval build ups. Alternatively, they could be non-traditional security threats such as conflicts over fishing, oceanic pollution, natural disasters or maritime piracy (Paik, 2005: 15; Liss, 2013: 141; Wirth, 2012: 223). Asian waters are particularly significant because they sit at the centre of international trade and shipping routes (Baird, 2012: 501). Trade flowing through Asian waters is both interregional and intraregional and played an integral role in promoting the economic growth of both Northeast and Southeast Asia (Baird, 2012: 502-503). According to Allessio Patalano, East Asia is a maritime system and historically the sea "constituted the region's main connecting fabric with shipping routes providing the highways for trade, transport and the projection of power across 


\section{AFRICAN \\ EAST-ASIAN \\ AFFAIRS \\ THE CHINA MONITOR}

its most remote corners" (Patalano, 2012: 222). For East Asia, regional maritime security issues are especially important given the high degree of economic interdependence and connectivity.

Japan is an island nation, or more accurately an archipelagic nation, in an interconnected maritime system (Patalano, 2012: 222). This has profound implications for Japanese economic security and explains why contemporary maritime piracy can be viewed as a threat to national security. Fundamentally, piracy is an economic crime which has the potential to upset the flow of raw materials to Japan and finished products out of Japan. Japan has a complicated relationship with the sea. It is a source of both security and vulnerability. For centuries, insular geography kept the world at bay, creating a spatial and cognitive differentiation between Japan and the Asian mainland (Yamaguchi, 2012). Kamikaze winds and tempestuous seas helped prevent the Mongol invasions centuries ago, for example. The sea is also an important source of food security. However, with the onset of modern transport and trade networks coupled with Japanese industrialisation and economic development, the seas became a source of vulnerability. In fact, Euan Graham (2006) characterises the protection of sea lines of communication (SLOCS) a matter of "life and death" for Japanese economic health and therefore national security. Concerns over maritime trade have historically informed developments in Japanese security posture. For example, Patalano (2008) demonstrates that the JMSDF fielded a sizable submarine force to keep an eye on Soviet maritime activities Northeast Asian waters and safeguard sea lanes. Additionally, in 1981 Japanese policy-makers decided to extend JMSDF patrols to 1,000 nautical miles in response to US demands for increased security burdensharing (Samuels, 2007: 89). In fact, Samuels (2007: 144) highlights the fact that current Sino-Japanese territorial disputes over the Senkaku/Diaoyu islands have profound implications for Japanese sea lane security. The protection of maritime trade networks is important to Japan and as those networks extend beyond the East Asian region and into the Indian Ocean region, for example, Japanese maritime security interests must follow (Kotani, 2011). Threats to sea lane security can emanate from traditional sources, such as the Union of Soviet Socialist Republics (USSR) during the Cold War or China's rise. Alternatively, they can come from non-traditional 
AFFAIRS

sources, like piracy. For example, Graham (2006: 25-31) and Black (2014: 117) note that piracy-induced trade blockages, in the Malacca Straits or Gulf of Aden, have the potential to seriously undermine Japan's economic health. If such a blockage were to occur, ships en route to Japan would have to be rerouted, costing roughly US\$ 200,000 to US\$ 300,000 per ship (Black, 2014: 117). Acts of piracy also have a more indirect cost. Ships occasionally have to hire private security or install other security measures, like location device ShipLoc or Secure Ship, a kind of electric fence. These added costs produce a more expensive but secure shipping industry. However, the need for more secure shipping is detrimental to the Japanese consumer because the price of goods goes up (Black, 2014: 2). This is on top of the safety risks posed by maritime piracy to Japanese citizens who work in the shipping industry (Bradford, 2004: 486). Therefore, the issue of piracy speaks to Japanese concerns over the nation's economic well-being and highlights Japan's dependency on maritime trade.

\section{Whatever floats your boat: JMSDF vs JCG}

Japan has two primary maritime security organisations. The first is the JMSDF and the second is the JCG. The latter organisation has taken on an increasing number of maritime threats since the end of the Cold War, such as incursions by North Korean "suspicious ships" and anti-piracy cooperation with Southeast Asian and East African states (Black, 2014: 2). Importantly, for this paper, the JCG is the Japan's primary anti-piracy organisation. While the JMSDF patrols the Gulf of Aden and escorts ships through troubled waters, officials from the JCG have to be on-board and they are the people with the authority to board suspicious vessels and make arrests (MOFA, 2009, 2016). Additionally, the JCG is involved in a variety of capacity building initiatives with littoral states in both Southeast Asia, another piracy hotspot, and the Gulf of Aden (MOFA, 2006, 2016). The increasingly important role of the JCG in meeting maritime threats has led some analysts to speculate that Tokyo uses it to test the waters, so to speak, for the eventual "normalisation" of the JMSDF's international security role. David Leheny (2006: 165) invokes the "canary in a coal mine" metaphor to describe this idea. Richard Samuels (2008: 97-98) argues that the JCG has become a second navy and fulfils the same function as a regular military. 


\section{AFRICAN \\ EAST-ASIAN \\ AFFAIRS

Consequently, the JCG's role in combatting various maritime security issues is seen as an erosion of Japanese pacifist norms.

Lindsay Black, however, argues that conflating the JMSDF and JCG is misguided (Black, 2014: 4). Both organisations serve different functions and are governed by very different legislations. For example, the JCG is a civilian law enforcement, disaster relief and emergency response organisation housed within Ministry of Land, Infrastructure, Transport and Tourism (MLITT). Contrastingly, the JMSDF is housed within the Ministry of Defence (MOD) and its mission is to defend Japan's territorial integrity (Black, 2014: 4). Historically, the JCG evolved out of the Maritime Safety Agency (MSA). The MSA was created to combat organised crime in Japanese coastal waters and the fact that the fundamental purpose of the JCG is law enforcement alleviates East and Southeast Asian concerns over Japanese remilitarisation and makes them more amenable to working alongside and learning from the JCG (Black, 2014: 4; Sato, 2007: 3; Bateman, 2006: 50-51). The prominence of the JCG in responding to maritime threats demonstrates the importance of domestic antimilitarist norms and regional concerns regarding Japan's military posture in shaping Tokyo's response to piracy and other emergent maritime threats (Black, 2014: 5). Norms, therefore, have an important role to play in determining what range of policy options are available to Japan.

\section{Piracy in the Gulf of Aden and the Horn of Africa}

Attacks by pirate gangs off the coast of Somalia increased rapidly in the early 2000s. The most common kind of attack is kidnapping for ransom. Pirates will board ships and hold the crew hostage. Then, they will extort large sums from shipping companies in exchange for the safe return of the crew and the cargo (Kraska and Wilson, 2009: 223; Beckman and Davenport, 2014: 145). Piracy in this region has a significant impact on international shipping because of its proximity to the Suez Canal. The attacks have been noted for their boldness and violence. A total of 42 vessels were captured by pirates in 2008. This jumped up to 114 attacks in the first five months of 2009 (Kraska and Wilson, 2009: 223). Political instability and economic deprivation in Somalia are the primary drivers behind the rapid growth in regional maritime 
crime. The overthrow of the Islamic Courts Union (ICU), a group of Sharia courts that governed most of Somalia after the collapse of Said Barre's regime in 1991, by joint Ethiopian and Somali transitional government forces was a particularly important development. There is a significant correlation between the fall of the ICU and the dramatic increase in piratical attacks (Pham, 2010: 329-330; Chalk, 2010: 90 -94). Governmental collapse is also evident in the way Somali pirates defined themselves. Pirates would often refer to their actions as collecting a "fishing tax" and that they were taking it upon themselves to police illegal fishing in lieu of the government's ability to do so (Kraska and Wilson, 2009: 224-225). The UN Security Council (UNSC) was quick to respond to piracy in the Gulf of Aden and Horn of Africa. It issued resolutions 1816 and 1846 calling on all nations to work together to combat piracy and secured the permission to the Somali transitional government to allow foreign vessels to conduct anti-piracy missions in Somalia's territorial waters (UNSC, 2008). Shortly after, the UNSC also called on states engaged in anti-piracy missions to cooperate with states willing to charge and prosecute pirates, such as Kenya (Gathii, 2010: 416). Japan would become one of those states in 2009 with the passage of its own anti-piracy law. Under Japan's anti-piracy law, four Somali nationals were prosecuted for their involvement in the attempted hijacking of the $M V$ Guanabara in 2011 (Hayashi, 2010: 143; MOFA, 2016). Combined Task Force 151 (CTF-151), a multilateral anti-piracy force comprised of 31 states, was established as a consequence of the multiple UNSC resolutions. The European Union (EU) also dispatched its EU Naval Force (Chalk, 2010: 97-99). Piracy in the Gulf of Aden and around the Horn of Africa resulted from a mixture of government collapse and economic deprivation within Somalia. The international reaction to it was swift and encouraged a variety of multilateral military initiatives to contain the threat to international trade.

\section{Japan's contributions to anti-piracy operations off the coast of Somalia}

Japan has initiated reforms to its own legal code to combat maritime piracy, actively contributes to UN missions in the region and made financial contributions to aid local coast guards, of which Djibouti, Somalia and Yemen are prominent beneficiaries (MOFA, 2016). Japan enacted an anti-piracy law in 2009 which allows the MSDF to 


\section{AFRICAN \\ EAST-ASIAN \\ AFFAIRS \\ THE CHINA MONITOR}

protect both Japanese and foreign-owned ships from pirate attacks and escort them through dangerous waters. Japan has also enacted legal reforms which allow privately-owned Japanese ships to hire armed security capable of shooting pirates in the event of an attack. Since 2009, two MSDF vessels have been deployed to the Gulf of Aden to combat maritime piracy and aboard each is a contingent of JCG officials equipped with the necessary authority to arrest pirates. Indeed, four Somali nationals were charged and convicted under Japanese law for the attempted hijacking of the MV Guanabara in waters near Oman in 2011 (Japan Times, 2011; MOFA, 2016). In addition to the two MSDF ships, Japan has deployed two P-3C maritime patrol aircraft. Between June 2009 and June 2015, the two planes conducted over 1,000 patrols. In order to support maritime and air patrols and escort missions, Japan constructed a military base in Djibouti in 2011 with the support of the Djibouti government (MOFA, 2016; 2009). Japan has participated in the UN-mandated Combined Task Force 151 (CTF-151) zone-defence activities in addition to the MSDF's own escort missions. Additionally, CTF-151 was under Japanese command for a threemonth period in 2015. Japan also participates in multilateral dialogues associated with its membership in the Contact Group on Piracy off the Coast of Somalia (MOFA, 2016). The Contact Group was established following the passage of UN Resolution 1851, an anti-piracy resolution (MOFA, 2016; UN, 2008). In addition to its own efforts and UN-initiated ones, Japan works to enhance the coast guard capabilities of regional states, notably Djibouti, Yemen and Somalia, via training exercises, technical assistance and providing patrol boats. It also contributes financially to anti-piracy initiatives via the International Maritime Organisation (IMO) Djibouti Code Trust Fund, a Japan-initiated fund aimed at capacity-building programs in Somalia and neighbouring states. Additionally, Japan provides funds to the Regional Cooperation Agreement on Combatting Piracy and Armed Robbery against Ships in Asia (ReCAAP) Information Sharing Centre on an ad-hoc basis. The purpose of these funds is to promote dialogue between Southeast Asian and East African states regarding their experiences of maritime piracy (MOFA, 2016).

\section{Japan and Somali piracy - domestic factors defining Japanese engagement}

The Japan Ship Owners Association (JSA) played an important role in drawing gov- 
AFFAIRS

ernment attention to the issue of piracy in the Gulf of Aden. It did this by lobbying the Japanese government to tackle piracy in after the number of attacks in that region increased in 2008. The 2008 attack on the Takayama and subsequent JSA lobbying was a particularly important catalyst for Japanese government involvement in the issue. Initially, the JSA contacted Iwazaki Teiji, an official at the Ministry of Land Infrastructure and Transport (MLIT) (Black, 2012: 268-269; 2014: 136). MLIT is the Japanese government ministry which oversees the JCG. Mr Iwazaki confirmed that the JCG was unable to tackle piracy around Somalia because it lacked the operational capacity to do so. Shortly thereafter, the Japanese government set up several ODA initiatives in the Gulf of Aden and brought the Draft Law on the Penalisation of Acts of Piracy before the Diet, Japan's parliament, in 2009. The law included a role of the JMSDF in anti-piracy operations. The Diet debate following this submission limited the role of the JMSDF and ensured that the primary responsibility for combatting piracy lay with the JCG. For example, only JCG officials are allowed to board suspected pirate vessels and have the authority to arrest suspected pirates (MOFA, 2009, 2016; Christofferson, 2009: 140; Black, 2012: 272, 2014: 135-136).

Japan's counter-piracy initiatives in the Gulf of Aden were the result of a discursive process between the Liberal Democratic Party (LDP)-Komeito alliance and multiple Japanese opposition parties, most notably the Democratic Party of Japan (DPJ). The various Japanese opposition parties were determined to uphold the anti-militarist norms embedded in Japan's constitution and undermine the ruling LDP's political standing. The LDP government under Aso Taro was very unpopular and the opposition parties controlled the Upper House of the Diet. Consequently, opposition parties were determined to challenge the government on any new legislation as the continued failure to pass new laws would force a snap election (Japan Times, 2009a; Black, 2012: 269). Challenging the constitutionality of dispatching the JMSDF to combat piracy in the Gulf of Aden provided an opportunity to do so. With this in mind, government policy-makers had to craft anti-piracy measures in such a way that opposition parties would be unable to fault their constitutionality. Therefore, the government highlighted the fact that piracy is a criminal issue rather than a military issue. Consequently, the JMSDF was there to support the JCG in its law enforcement 


\section{AFRICAN \\ EAST-ASIAN \\ AFFAIRS

duties, not the other way around. Additionally, the JMSDF was limited to escort and surveillance duties whereas the JCG would be the organisation invested with the authority to actually arrest pirates and board their boats (Japan Times, 2009b; Christofferson, 2009: 140; Black, 2012: 272; 2014: 135-136). The government also argued that all dispatching Japanese officials would complement rather than replace capacity building initiatives amongst regional states like Djibouti and Yemen and ODA-led approaches (Black, 2012: 276). Overall, the debate around the constitutionality of dispatching Japanese officials to combat maritime piracy highlights the fact that anti-militarist norms play an important role in shaping the content of Japanese security policies.

\section{Conclusion}

This paper examined Japan's efforts to combat piracy off the coast of Somalia. It has argued that Tokyo's response to piracy demonstrates the continued importance of domestic anti-militarist norms in moulding Japan's response to piracy. Opposition parties were eager to challenge the constitutionality of the planned JMSDF dispatch and consequently the LDP-led government developed a policy in which the JCG, a civilian law-enforcement body, played the primary role. Additionally, this paper posited that maritime threats, like piracy, are particularly important for Japanese policy-makers because of the potential disruptions of shipping lanes have profound implications for Japan's economic security. 
AFFAIRS

\section{Bibliography}

Akaha, T. 1991. Japan's comprehensive security policy: a new East Asian environment. Asian Survey, 31(4):324-340.

Aoi, C. 2012. Punching below its weight: Japan's Post-Cold War Expeditionary Missions, in Patalano (eds.). Maritime strategy and national security in Japan and Britain: From the first alliance to post-9/11. Leiden: Brill.

Baird, R. 2012. Transnational security issues in the Asian maritime environment: responding to maritime piracy. Australian Journal if International Affairs, 66 (5):501-513.

Bateman, S. 2006. Regional responses to enhance maritime security in East Asia. Korean Journal of Defence Analysis, 18(2):25-53.

BBC News. 2014. Japan man self-immolates in protest over military shift. [Online]. Available: http://www.bbc.com/news/world-asia-30015841 [Accessed: 10 July 2016].

Beckman, R., and Davenport, T. 2014. Enhancing regional cooperation on piracy and maritime crimes, in $\mathrm{Wu}, \mathrm{S}$ and Zou, $\mathrm{K}$ (eds.). Non-traditional security issues and the South China Sea: Shaping a new framework for cooperation. Surrey: Ashgate.

Black, L. 2012. Debating Japan's intervention to tackle piracy in the Gulf of Aden: Beyond mainstream paradigms. International Relations of the Asia-Pacific, 12: 259-285.

Black, L. 2014. Japan's maritime security strategy: The Japan Coast Guard and maritime outlaws. London: Palgrave MacMillan.

Bradford, J. 2004. Japanese anti-piracy initiatives in Southeast Asia: Policy formulations and the coastal state responses. Contemporary Southeast Asia, 26(3):480505.

Coggins, B. 2012. Global patterns of maritime piracy, 2000-2009: Introducing a new 
AFRICAN

EAST-ASIAN

AFFAIRS

dataset. Journal of Peace Research, 49(4):605-617.

Chapman, J, Drifte, R., and Gow, I. 1983. Japan's quest for comprehensive national security: Defence, diplomacy, dependence. London: Frances Pinter Publishers.

Chalk, P. 2010. Piracy off the Horn of Africa: Scope, dimensions, causes and responses. Brown Journal of World Affairs, 16(2):89-108.

Chalk, P., and Hansen, S. 2012. Present day piracy: Scope, dimensions, dangers and causes. Studies in Conflict and Terrorism, 35(7-8):597-506.

Christofferson, G. 2009. Japan and the East Asian maritime security order: Prospects for trilateral and multilateral cooperation. Asian Perspective, 33(3):107-149.

Delamotte, G. 2012. The political and normative constraints to Japan's national security, in Patalano (eds.). Maritime strategy and national security in Japan and Britain: From the first alliance to post-9/11. Leiden: Brill.

Friman, R. et al. 2006. Immovable object? Japan's security policy in East Asia, in Katzenstein, P., and Shiraishi, T. (eds.). Beyond Japan: The dynamics of East Asian regionalism. Ithaca, New York: Cornell University Press.

Gathii, J. 2010. Kenya's Piracy Prosecutions. The American Journal of International Law, 104 (3):416-436.

Graham, E. 2006. Japan's sea lane security, 1940-2004: A matter of life or death. London: Routledge.

Green, M. 2001. Japan's reluctant realism: Foreign policy challenges in an era of uncertain power. New York, New York: Palgrave.

Hayashi, M. 2010. Current legal developments in Japan. The International Journal of Marine and Coast Law, 25:143-149.

Heginbotham, E., and Samuels. R. 1998. Mercantile realism and Japanese foreign policy. International Security, 22(4):171-203.

Hook, G et al. 2012. Japan's international relations: Politics, economics and securi- 
AFFAIRS

ty. London: Routledge.

Hughes, C. 2004. Japan's re-emergence as a "normal" military power. London: Routledge.

Hughes, C. 2014. Japan's foreign and security relations, in Pekkanen Ravenhill, J and Foor, R. (eds.). The Oxford Handbook of the International Relations of Asia. Oxford: Oxford University Press.

Japan Times. 2009a. Debate starts on bill to free up MSDF. [Online]. Available: http://www.japantimes.co.jp/news/2009/04/15/national/debate-starts-on-bill-tofree-up-msdf/\#.V9ggLFe9Hq0 [Accessed: 15 July 2016].

Japan Times. 2009b. Piracy and the constitution. [Online]. Available: http:// www.japantimes.co.jp/opinion/2009/03/26/commentary/world-commentary/ piracy-and-the-constitution/\#.V9ggLFe9Hq0 [Accessed: 15 July 2016].

Japan Times. 2014. Protecting the peace constitution. [Online]. Available: http:// www.japantimes.co.jp/opinion/2014/05/02/editorials/protecting-the-peaceconstitution/\#.V9gpDFe9FmA [Accessed: 15 July 2016].

Jansen, M. 2000. The Making of Modern Japan Cambridge, Massachusetts: Harvard University Press.

Katzenstein, P., and Okawara, N. 1993. Japan's national security: structures norms and policies. International Security, 17(4):84-118.

Katzenstein, P., and Okawara, N. 2008. Japan's security policy: political economic and military dimensions, in Katzenstein, P. (eds.). Rethinking Japanese security: internal and external dimensions. London: Routledge.

Kotani, T. 2011. Lifeline at sea: Japan's policy toward the Indian Ocean region. Journal of the Indian Ocean Region, 7 (2):220-234.

Kraska, J., and Wilson, B. 2009. The global maritime partnership and Somali piracy. Defence and Security Analysis, 25(3): 223-234. 


\section{AFRICAN \\ EAST-ASIAN \\ AFFAIRS

Prime Minister of Japan and his cabinet. 1947. The constitution of Japan. [Online]. Available: http://japan.kantei.go.jp/constitution_and_government_of_japan/ constitution_e.html [Accessed: 9 July 2016].

Leheny, D. 2006. Think global fear local - sex, violence and anxiety in contemporary Japan. Ithaca, New York: Cornell University Press.

Ministry of Foreign Affairs (MOFA). 2016. Japan's actions against piracy off the coast of Somalia. [Online]. Available: http://www.mofa.go.jp/policy/piracy/ ja_somalia_1210.html [Accessed: 15 July 2016].

Ministry of Foreign Affairs (MOFA). 2009. Talks between H.E. Mr Hirofumi Nakasone and H.E. Mr Mahmoud Ali Youssouf, Minister of Foreign Affairs and International Cooperation of the Republic of Djibouti. [Online]. Available: http://www.mofa.go.jp/announce/announce/2009/4/1190255_1132.html [Accessed: 10 July 2016].

Midford, P. 2011. Rethinking Japanese public opinion and security: from pacifism to realism. Stanford, California: Stanford University Press.

Mearsheimer, J. 2001. The tragedy of Great Power politics. New York: Norton.

Paik, J. 2005. Maritime security in East Asia: Major issues and regional responses. Journal of International and Area Studies. 12(2):15-29.

Patalano, A. 2008. Shielding the "Hot Gates:" submarine warfare and Japanese naval strategy in the Cold War and Beyond (1976-2006). Journal of Strategic Studies. 31(6):859-895.

Patalano, A. 2012. Conclusion: Maritime strategy in Japan and the UK: the 'Island Nation' model in perspective. In: Patalano (ed.). Maritime strategy and national security in Japan and Britain: From the First alliance to post-9/11. Leiden: Brill.

Pham, J. 2010. Putting Somali piracy in context. Journal of Contemporary African Studies. 28(3):325-341

Samuels, R. 2007. Securing Japan: Tokyo's grand strategy and the future of East 
AFRICAN

AFFAIRS

Asia. Ithaca, New York: Cornell University Press.

Samuels, R. 2006. Japan's Goldilocks Strategy. The Washington Quarterly. 29 (4):111-127.

Samuels, R. 2008. “New fighting power!” Japan's growing maritime capabilities and East Asian security. International Security. 32(3):84-112.

United Nations Security Council (UNSC). 2008. Press release: Security Council asks nations with military capacity in area to 'actively fight piracy' on high seas off Somalia. [Online]. Available: http://www.un.org/press/en/2008/ sc9467.doc.htm. [Accessed: 10 July 2016].

Yamaguchi, N. 2012. Balancing threat perceptions and strategic priorities: Japan's post-war defence policy, in Patalano (eds.). Maritime strategy and national security in Japan and Britain: From the First alliance to post-9/11. Leiden: Brill.

Yoshihara, T., and Holmes, J. 2008. Japan's emerging maritime strategy: Out of sync or out of reach. Comparative Strategy, 27(1):27-53.

Yoshimatsu, H. 2014. Economic-security linkages in Asia, in Pekkanen Ravenhill, J and Foor, R. (eds.). The Oxford Handbook of the International Relations of Asia. Oxford: Oxford University Press. 